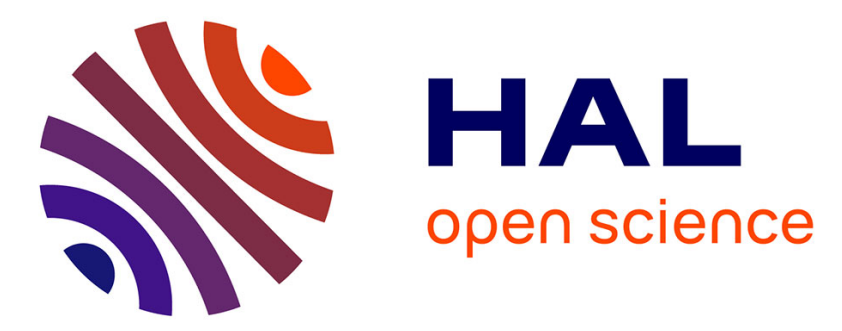

\title{
Grotta Piatta New Results From Corsican Burials of the Iron Age
}

\author{
Marie-Laurence Marchetti
}

\section{To cite this version:}

Marie-Laurence Marchetti. Grotta Piatta New Results From Corsican Burials of the Iron Age. Jul 2006, pp.482-486. hal-00138481

\section{HAL Id: hal-00138481 \\ https://hal.science/hal-00138481}

Submitted on 30 Mar 2007

HAL is a multi-disciplinary open access archive for the deposit and dissemination of scientific research documents, whether they are published or not. The documents may come from teaching and research institutions in France or abroad, or from public or private research centers.
L'archive ouverte pluridisciplinaire HAL, est destinée au dépôt et à la diffusion de documents scientifiques de niveau recherche, publiés ou non, émanant des établissements d'enseignement et de recherche français ou étrangers, des laboratoires publics ou privés. 


\title{
Grotta Piatta New Results From Corsican Burials of the Iron Age
}

\author{
Marie-Laurence Marchetti \\ Groupe de Recherches Préhistoriques et Protohistoriques \\ Université de Corse Pascal Paoli \\ Caserne Padoue 20250 Corte \\ FRANCE \\ marchetti@univ-corse.fr
}

\begin{abstract}
The funerary practices in shelter of the Iron Age in Corsica are characterized by diversity from the developed sepulchral modes - individual, collective or multiple burials, primary and secondary deposit, pratice of inhumation and cremation. These funerary modes translate the various men's behaviours towards death through a type of tomb - shelters. The Grotta Piatta site's results (Aregno, North Corsica) recently studied, are presented.

These data analysis will describe us the vision of death at the Iron Age, taking into account the sometimes fragmentary data we have.
\end{abstract}

\section{INTRODUCTION}

About twenty funerary shelters were discovered in the island. These sheltered burials were the favourite place for men to bury their lates. There they made various facilities and practiced different funerary modes. These burials seem to be the type of tomb the most widespread of this period. Various types of cavity falls into the shelters terminology, such as: caves, shelters open shed or "tafoni". This Corsican term indicates cavities dug by the natural erosion of rock where man made alterations.

\section{BURIALS}

\section{A. The Structures}

Shelters used as burial are low-sized $\left(2-6 \mathrm{~m}^{2}\right)$, few sites are characterized by more important dimensions (Nulachiu, Cime, Morsaja [11]). Contributions are very various and sometimes singular. The well-defined structures where bodies were deposited are well-delimited pits like the burials of Roja [18] and of Monte Lazzu [21] or more atypical, burials of Cime or Capula. In the first case, they are stones of

Various dimensions which delimit sepulchral space forming a grave. In addition to this, there is the stone contribution in the shelter's different openings to protect the grave.

A structure stands out, it is the only one of this type discovered under a rock open shed. Capula burial [9] is a chest $(1.7 \mathrm{~m}$ in length $\mathrm{x} 0.30 \mathrm{~m}-0.70 \mathrm{~m}$ in width and 0.20 $0.30 \mathrm{~m}$ in height) constituted of granite flagstones where a female subject was buried. Close to one of the chest's flagstones, a hearth was used for a funerary meal [9]. Indeed, a significant number of faunal remainders was discovered [20]. Another tomb gives particular alterations, it is the burial of Cime [11]. The main installation was an artificial terrace composed of a dry stone wall in a circulare arc. It was established in the broadest space and rests in the North against the shelter wall. Human remainders were placed on a bed of stones.

In the other cases, the structures very often correspond to pavements carried out using flagstones of variable size. The late ones were deposited there. Sometimes, a pavement of cover is added.

Open spaces were very often filled with stones or clay (Nulachiu [13]-[14]-[15], Strappazzola [16]) in order to protect the deposit.

\section{B. The Mortuary Practice}

In about twenty of studied sites, only the Capula burial corresponds to an individual deposit, all the others belonging to collective ${ }^{1}$ deposits. As regards the mode of deposit, we can notice, the primary ${ }^{2}$ deposit practice as well as the secondary one [4]. The number of buried lates varies from 2 to 10 [19], it reveals these burials were used as true "burial vaults" where members of the same group had to be buried after deaths differed in time. This implies a particular management of the tomb where this one was opened with each new death and where upheavals of the preceding deposits were carried out.

We do not exclude that several subjects wee buried at the same time (multiple deposit). But that supposes simultaneous deaths whose anthropological pathological causes could not be given for the studied sites. Sometimes, certain sites show of a particular and more marked management of the deposits. Thus, they could be made in distinct zones. Some buried were laid out on living with stones, others in a natural recess (Strappazzola).

The type of burial seems to be marked by the cremation practice (Cime, Lugo [7]...). Nevertheless, although many bones carry traces of calcination, the use of an intentional practice is more complex to determine. We have to stress that the anthropological studies are not systematic (old works). So, certain sites suffer from the insufficiency of data to interpret with certainty the mortuary practice employed [3].

\footnotetext{
1 Collective deposit: burials differed in time, by opposition to the multiple deposit having received simultaneous deposits.

${ }^{2}$ Primary deposit: fall in only one time, the body was buried without preliminary action as of the death in opposition to the secondary burial where the deposit was preceded by an active or passive phase of a mortuary pratice.
} 


\section{The Furniture}

The furniture accompanying or deposited with the lates is very diversified, and not homogeneous for all the sites. Very often disparate, due to the various upheavals among which many plunderings, it is mainly laid out without particular organization. The ceramic vestiges are local or importated, they correspond to pottery of very varied sizes and dimensions. The rich metal vestiges, are objects from vestimentary ornament, finery or equipment. They are the pendeloques, fibules, belt fasteners... They can have belonged to the late or have been the subject of an deposit of offerings. At Parata, the finder signale that the late carried objects of ornament (bracelets and rings) to the wrists and ankles [18].

The considerable small glassware, relates to pearls of any kind, polychrome or monochromic, of diversified forms, spherical, annular, tubular, cylindrical..., very often, in a significant number. A singular fact, in very many cases white glass shots are widespread in large quantities (Teppa di Lucciani, moreover 40000 pearls [1], San Simeone, 1340 pearls [5]). Some researchers interpret this proportion as a form of "ritual", where pearls were disseminated inside the burial [1].

Other offerings were also revealed. This is the case of Nulachiu where a small chest containing the remainders of one bovidae is interpreted by the archaeologist as an offering deposit [14]-[15].

The data we have correspond to old work in which anthropological analysis and field anthropology methods were not systematically carried out. Moreover, the sites were subjected to upheavals and plunderings, hence the many problems to define exactly the mortuary practice employed and how the structures were organized. However, we hope that new undertaken work, such as the excavation of the Grotta Piatta site, will bring new data and widen our knowledge about the funerary modes of Corsican protohistorics.

\section{LA GROTTA PIATTA, AREGNO}

Grotta Piatta (Fig. 1) is located in Aregno plain (North Corsica) within an important granitic solid mass in which there are many shelters. Discovered in a fortuitous way, two archaeological operations ${ }^{3}$ were carried out, an evaluation survey in 2004 [22] and the complete shelter excavation the following year [23]. The shelter is composed of a principal opening (locus III), site of the excavation. It is prolonged downwards in the West (locus I) by one opening and then by a second one (locus II) located under the principal entry. It opens on a small terrace.

\footnotetext{
3 This work (arrêtés préfectoraux - 2004/012 et 2005/011) was supported in part by le Service Régional de l'Archéologie - la Collectivité Territoriale de Corse - le Groupement Régional des Sociétés Archéologiques de Corse - la Mairie d'Aregno.
}

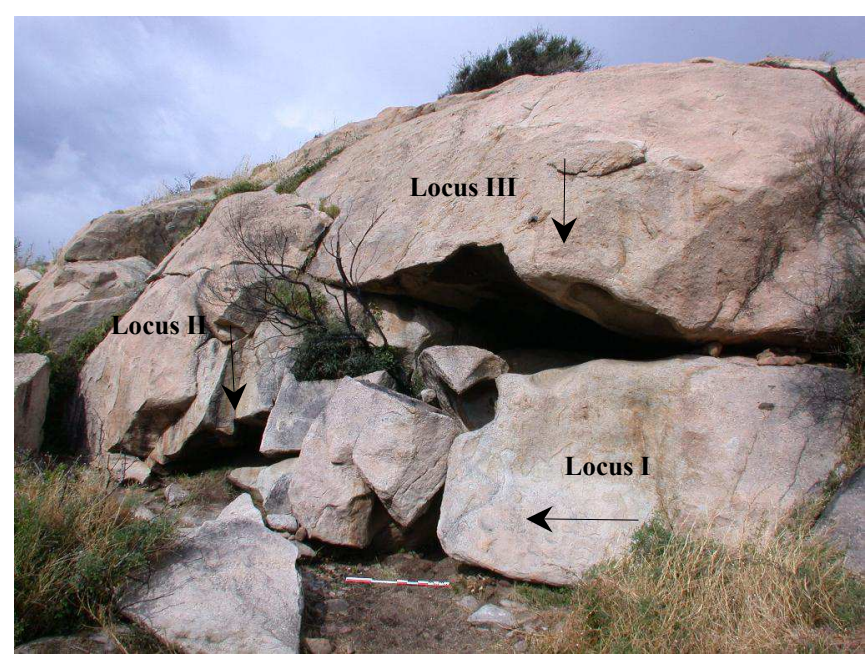

Fig. 1. Grotta Piatta (cl. M.-L. Marchetti)

\section{A. The Study}

The excavation carried out allowed to individualize various levels, in which there were many stones without particular organization. However, blocks of more important dimensions and greater thicknesses (40 to $60 \mathrm{~cm}$ in thickness) were revealed. They must have been used to arrange a funerary structure (pavement?) today destroyed by the successive upheavals. Indeed, we were not able to determine the level which was subjected to sepulchral occupation. Initially, we think that the numerous stones, very often thin in thickness $(2$ to $5 \mathrm{~cm}$ ), are the fact of the vault and the shelter granitic walls disintegration. Moreover, collected furniture is dispersed on all the surface, in various levels. This is due to the sediment nature, sandy and very moving, which functioned certainly like a "funnel" making a great part of the vestiges run out in the subjacent levels.

In addition to this phenomenon, there is a natural slope of the ground which may have dragged elements towards the Western sector, at the time of the successive shelter upheavals. Added to these various phenomena at the origin of upheavals, there are two faults in Eastern and Western zones. These faults thus form slides of sediment which involve a part of the vestiges and flow either in the locus I (sector Is) or in the locus II (Western sector). Originally, they were to be blocked by flagstones.

\section{B. The Funerary Deposit}

Approximately 200 human vestiges were collected. They were mainly long bones, elements in lengthower and higher limbs (humerus, tibia, fibula, talus, patella, femur,...), but also of other parts of the skeleton (hip bone, scapula, vertebrae...), of a part of a cranium and a mandible very well preserved. Some of these elements, in particular cranial, seem to have undergone the action of fire. Vestiges are of variable conservation; some are very faded and many fragments (splinter) were collected. These vestiges are distributed on 
the whole excavation whose main sector is the zone of balance (East).

The central sector poverty is due to the presence of an important block of stone which is impossible to move. As the shelter ground is slightly inclined, we do not exclude that some of the vestiges were moved during upheavals.

It seems that this burial functioned as a collective deposit. However, interrogations remain. Indeed, a significant number in lengthong bones was collected. On the contrary, only the cranial elements, one part of a cranium and a mandible were discovered. Is this due to the successive shelter upheavals or to an unspecified mortuary practice? The results of the anthropological study ${ }^{4}$ in progress will inform us on the funerary practice employed and the buried subjects.

\section{B. $\quad$ The Furniture}

The discovered material is mainly composed of metal vestiges and glass bead elements. Some of the bronze objects are oxidized and fragmented. They are elements of ornament and clothing.

Certain pieces of vestimentary ornament are distinguished including 3 plates (Fig. 2) which can belong to elements of belt or cuirass. The three plates have the same dimensions ( 9 $\mathrm{cm}$ in length $\mathrm{x} 3.5 \mathrm{~cm}$ in width and $0.1 \mathrm{~cm}$ in thickness). They are decorated with small three-line punches of an awl; 2 at the ends and one in the center. Hangs were realized by 3 small rings; 2 at the ends and one in the center. The ends are slightly curved, giving an aspect slightly rounded at the piece. As far as we know, there are no similar elements known in Corsica.

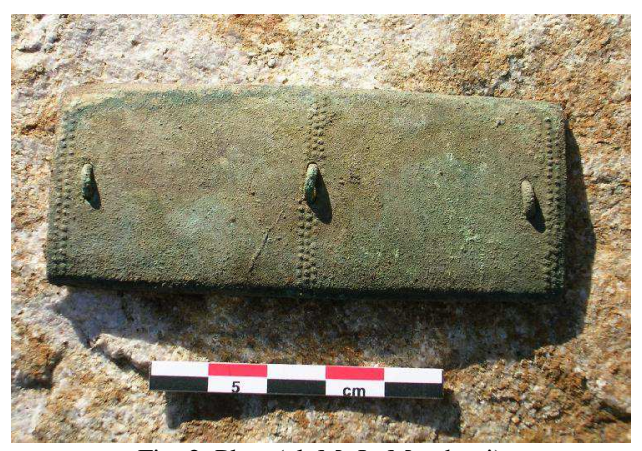

Fig. 2. Plate (cl. M.-L. Marchetti)

Another piece of vestimentary ornament, a plate, certainly a belt staples (Fig. 3). Its faded state of conservation (oxidized and fragmented), does not allow us to determine its function more. It is of circular form ( $4 \mathrm{~cm}$ in length $\mathrm{x}$ and 0.1 $\mathrm{cm}$ in thickness), decorated whith two central perforations.

\footnotetext{
${ }^{4}$ The anthropological study, in progress, was entrusted to Mrs. BoualiBuchet, attached to the Unit of Biological anthropology of the C.E.P.A.M./U.M.R. 6130 Valbonne and Mr. L Buchet, Director of the Laboratory of Biological anthropology of the C.E.P.A.M./U.M.R. 6130 Valbonne.
}

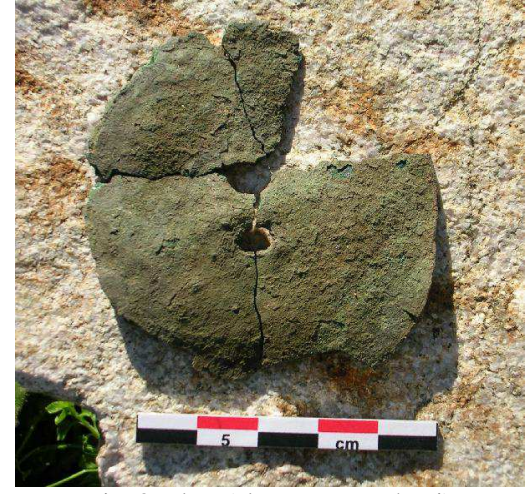

Fig. 3. Plate (cl. M.-L. Marchetti)

Another object is distinguished a bronze fastener (Fig. 4) of $4.9 \mathrm{~cm}$ in lenght, whose broad stem (of $0.5 \mathrm{~cm}$ to $2 \mathrm{~cm}$ ) is bent at its end. Realized with only one holding, the double stem is made of two symmetrical spirals.

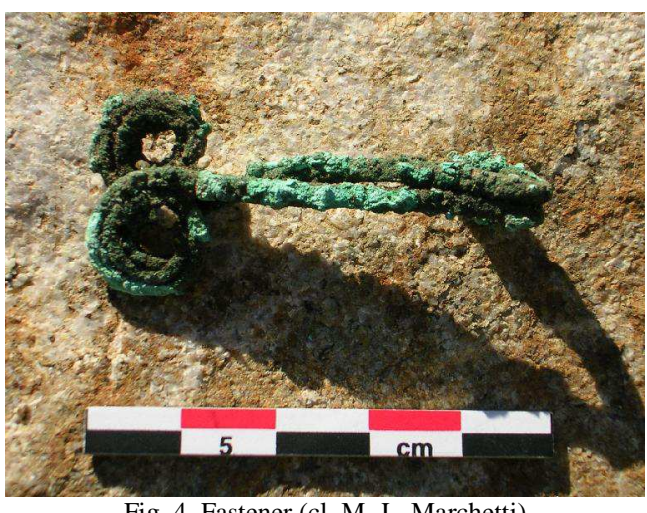

Fig. 4. Fastener (cl. M.-L. Marchetti)

Three parts intrigue, they are small bronze sheaths (Fig. 5) (3. $58 \mathrm{~cm}$ in length $\mathrm{x} 2 \mathrm{~cm}$ in width and $0.1 \mathrm{~cm}$ in thickness) whose edges are bent towards the interior without joining. Only one part carries on one of the sides a small ring. Indeed, the part is cracked. Thus, it must be a consolidation. This element looks like a small sheath because of its form, it could have been used as a piece of ornament to hold leather pieces for example...

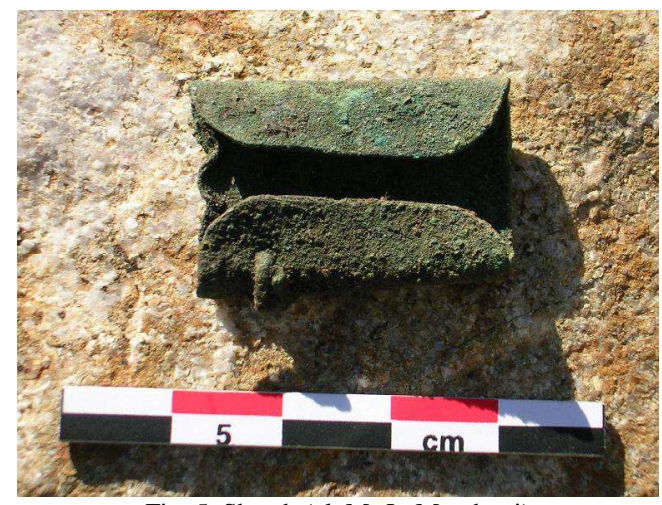

Fig. 5. Sheath (cl. M.-L. Marchetti) 
Three fibules were discovered, one of which "A navicella" is broken, only the semicircular arc of section is preserved (3. $8 \mathrm{~cm}$ in length), it seems decorated, notably by a small button in the arc center. The second large-sized one ( $8 \mathrm{~cm}$ in length) is broken, it misses the tongue, only a part of the spring is preserved. The door tongue measures $3.7 \mathrm{~cm}$ in length $\mathrm{x} 0.4$ $\mathrm{cm}$ in width the arc is of a particular semicircular section, it was repaired, consolidated by the addition of a riveted metal part. The last fibule whose arc has a semicircular section (6. 2 $\mathrm{cm})$ is broken at its two ends. These pieces are found in many sites of the island (U Luru [17], Santa Catalina [6], Lugo, Cagnanu ....).

The last piece of clothing is a single small button $(1 \mathrm{~cm})$, decorated in the center with a small protuberance. A small ring perforated at the back of the part allows the passage of the wire.

To these pieces are added the objects made of bronze referring to the ornament including one pendentive (Fig. 6), of circular form, (3. $5 \mathrm{~cm}$ in length $\mathrm{x} 3.4$ in width), broken in three parts, it carries a perforation of $1 \mathrm{~cm}$ in its center, probably to make a ring of suspension pass. It was decorated on all its surface with punched impressions. Only visible at the recto, this decoration does not appear on its too faded external face.

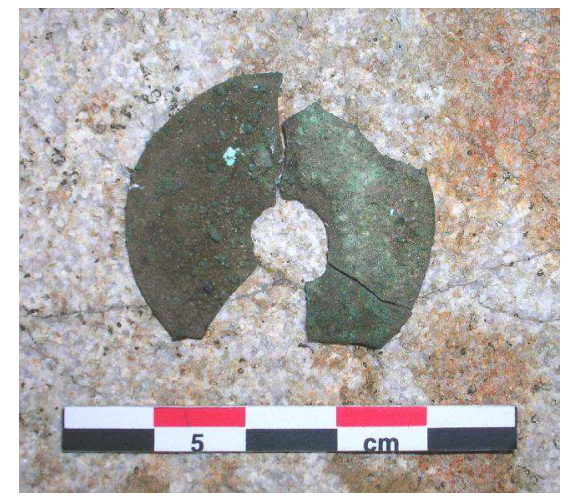

Fig. 6. Pendentive (cl. M.-L. Marchetti)

21 fragments of spiral tube were discovered, the destination of these vestiges is not cleared up. However, the use of these elements as object of ornament (collar) seems most plausible to us. Similar vestiges were found in several sites of the island (Cagnanu [2], Monte Lazzu, Teppa di Lucciani, Ordinaccio [8]...).

Other bronze pieces collected must belong to elements of vestimentary ornament and finery including 93 small rings of which many fragments, 42 fragments of small chains and 11 links of a chain. In addition to these metal vestiges, there are many formless, very damaged and oxidized iron fragments, of very diverse size and thickness. We don't know their function, only one element is recognizable; it is a large ring (2. $6 \mathrm{~cm}$ in diameter and 0.5 in thickness).
369 molten glass pearls ${ }^{5}$ (Fig. 7-8) compose the most represented pieces of ornament. They form a homogeneous whole by the forms and the colours (blue, gilded, white and colourless); these are mainly monochromic pearls among which some are characterized by their opaque color and their cylindrical or tubular form. Only one part is polychrome, it is blue and decorated with white ocelles. Others of tubular and particular form, have small protuberances on all their surface. A great part is of annular and spherical form. We note, as for the other sepulchral sites of the Corsican Iron Age, a strong proportion of annular white glass pearls; 221 of them are counted.

It's important to stress that many elements seem to us to belong to the category of the pearls with metal sheet (gold or money), so it would be pieces of importation.

A pendeloque is added to these objects of ornament. It is a polished stone ring very damaged $(0.8 \mathrm{~cm}$ in thickness and of $2.3 \mathrm{~cm}$ in diameter).

A singular fact, the ceramic ${ }^{6}$ vestiges are rare (21 shards), several elements are of importation, it is a black fine ceramic assembled to the turn. A composite spherical ceramic form was recognized.

Only one complete form was reconstituted, it is a spherical pottery, very eroded. The black paste is polished, it is decorated with two horizontal oval buttons laid out on the paunch.

Other shards in lengthocal making were discovered, amongwhich edges belonging to pottery of great forms.

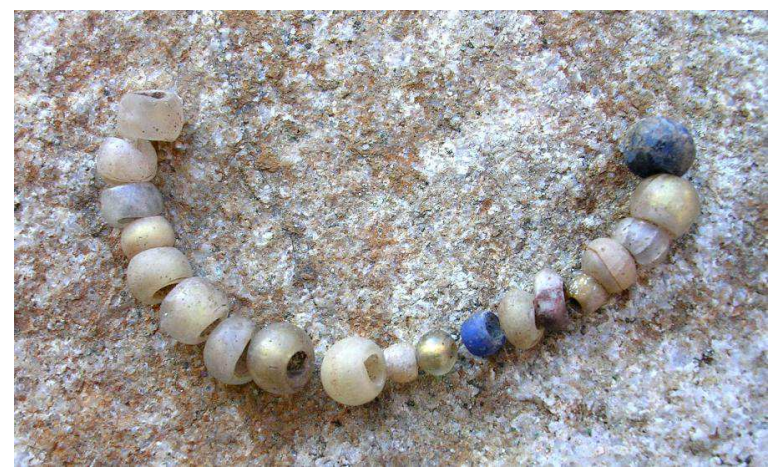

Fig. 7. Pearls (cl. M.-L. Marchetti)

\footnotetext{
${ }^{5}$ The study, in progress, was entrusted to Mr. B. Gratuze, Centre Ernest Babelon (University of Orleans), Laboratoire Imarat, U.M.R. 5060, C.N.R.S.

6 The study was carried out by Mrs. A. Nonza Micaelli, Phd of prehistoric archeology of the University of Corsica.
} 


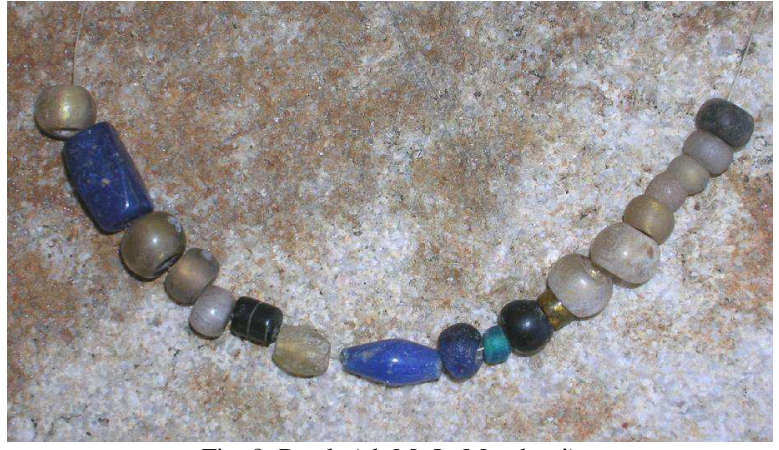

Fig. 8. Pearls (cl. M.-L. Marchetti)

\section{CONCLUSION}

The study of furniture enables us to estimate an occupation of the burial at the end of the $2^{\text {nd }}$ Iron Age. We find through the Grotta Piatta study many similarities with other sepulchral shelters, more particularly the furniture discovered. Although, because of the various upheavals, the organization of the structures was not recognized, we hope that the study of furniture, thanks to the various undertaken analysis (anthropological study, pearls analyzis: source, composition), will bring new exploitable data.

\section{ACKNOWLEDGMENT}

The authors gratefully acknowledge the contributions of pratical work S. Carcione, L. Castellani, A. Colonna, C. Marchetti, N. Marini, S. Mazet and J.-M. Bontempi. C. Bain and R. Loncle for their work on the original version of this document.

\section{REFERENCES}

\section{Periodicals:}

[1] A. Amadei, J.-C. Ottaviani et J. Magdeleine, "Une sépulture du premier Age du Fer dans le Nebbio", B.S.S.H.N.C., fasc. $675,3^{\mathrm{e}}$ et $4^{\mathrm{e}}$ trimestres, CII ${ }^{\mathrm{e}}$ année, Bastia, pp. 153-161, 1983.

[2] E Chantre, "La nécropole Proto-Historique de Cagnano, près de Luri (Corse)", Comptes rendus de l'Association française pour l'avancement des sciences, pp. 715-723, 1901.

[3] H. Duday, "Anthropologie de terrain archéologie" de la mort, in $\mathrm{La}$ mort, passé, présent conditionnel, Colloque du Groupe Vendéen d'Etudes Préhistoriques, La Roche-sur-Yon, pp. 33-58, 1995.

[4] H. Duday, P. Courteau, E. Crubezy, P. Sellier, A.-M. Tillier., "L'anthropologie de "terrain": reconnaissance et interprétation des gestes funéraires", Bulletin et Mémoire de la Société d'Anthropologie de Paris, n.s., t. 2, n³-4, pp. 29-50, 1990

[5] L. Doazan, Documents pré et protohistoriques aux portes d'Ajaccio, une sépulture, un habitat et une carrière dans le même abri sous roche, Corse Historique, $\mathrm{n}^{\circ}$ 27-28, Ajaccio, $3^{\mathrm{e}}$ et $4^{\mathrm{e}}$ trimestres 1967, pp. 5-30, 1967.

[6] R. Grosjean, "Chronique d'archéologie préhistorique III. Deux modes de sépultures dans le Nebbio", Etudes Corses, fasc. 17, pp. 37-46, 1958 .

[7] F. de Lanfranchi, "Communication préliminaire: les sépultures de Santa Catalina et de Cucuruzzu (Levie)", Corse Historique n ${ }^{\circ} 29-30$, Ajaccio, 1/2 trimestre 68, pp. 67-87, 1968.
[8] F. de Lanfranchi, "Une inhumation sous abri de l'Age du Fer à Lugo (Zonza, Corse) ", B.S.P.F., tome 68, 1971, Etudes et Travaux, fasc. 2, Paris, pp. 610-617, 1971

[9] F. de Lanfranchi et Ch. Luzi, "La grotte sépulcrale de l'Ordinaccio, Solaro (Corse)", Bulletin de la Société Préhistorique de l'Ariège, t. XXVI, pp. 127-140, 1971.

[10] F. de Lanfranchi, "Une veillée funèbre de la fin de l'Age du Fer", Actes des $3^{e}$ Rencontres Culturelles Interdisciplinaires de l'Alta Rocca, vol. 2, septembre 1992, Musée Départemental de Levie, pp. 9-14, 1992.

[11] J. Magdeleine, "La grotte de Morsaja à Poggio d'Oletta", Cahiers Corsica, $\mathrm{n}^{\circ} 29$, pp. 13-17, 1973.

[12] J.-C. Ottaviani et J. Magdeleine, Modes d'inhumations et rites funéraires en Corse durant l'Âge du Fer, Etudes Corses, vol. 7, n 12 13, pp. 59-63, 1979.

[13] J.-C. Ottaviani, A. Milleliri et J. Magdeleine, "La Teppa di Lucciani, nécropole protohistorique. Commune de Vallecale (Haute-Corse)", B.S.S.H.N.C., $\mathrm{I}^{\mathrm{er}}$ et $\mathrm{II}^{\mathrm{e}}$ trimestres, fasc. $\mathrm{n}^{\circ}$ 702-703, Bastia, pp. 7-81, 2003.

[14] A. Pasquet, "Nulachiu, Contribution à l'atlas préhistorique de la région de Porto-Vecchio", Archeologia Corsa, n²4, pp. 53-81, 1979.

[15] A. Pasquet, "La sépulture de Nulachiu, commune de Figari", Rapport de fouille, publication inédite, S.R.A., D.R.A.C., Ajaccio, 9 p., 1981.

[16] A. Pasquet, "La sépulture de Nulachiu, commune de Figari", Rapport de fouille, publication inédite, S.R.A., D.R.A.C., Ajaccio, 11 p., 1986.

[17] A. Pasquet, "La sépulture de Tozze Bianche - Strappazzola, commune de Zonza", Rapport de fouille, publication inédite, S.R.A., D.R.A.C., Ajaccio, 4 p., 1989.

[18] M.C Weiss, "Préhistoire et Protohistoire de la Corse Nord Occidentale: l'apport de quatre sites nouvellement étudiés", Archéologia Corsa, nº6-7, Saint-Étienne, pp. 65-82, 1981-1982.

Books:

[19] L Acquaviva, La Préhistoire et la Protohistoire des hautes vallées du centre Nord de la Corse. Nice : thèse de doctorat, U.E.R. civilisations, 1979, $284 \mathrm{p}$.

[20] H. David, Paléoanthropologie et pratiques funéraires en Corse, du Mésolithique à l'Age du Fer. Oxford: Bar international, series 928, 2001, 148 p.

[21] J.-D. Vigne, Etude archéozoologique : mammifères post-glaciaires de Corse, $26^{\mathrm{e}}$ supplément à Gallia Préhistoire, Paris : C.N.R.S., publié avec le concours du Ministère de la Culture, Direction Patrimoine sous Direction Archéologie, Paris, pp. 50-53, 1988.

[22] M.C. Weiss, Monte Lazzu, un site préhistorique et protohistorique de la Corse Occidentale. Oxford: Bar International series 222 ii, parti i, 1984, pp. 297-396.

\section{Technical Reports:}

[23] M.-L. Marchetti, "Grotta Piatta commune d'Aregno", Rapport de fouille, publication inédite, Ajaccio, S.R.A., D.R.A.C., janv. 2005.

[24] M.-L. Marchetti, "Grotta Piatta commune d'Aregno", Rapport de fouille, publication inédite, Ajaccio, S.R.A., D.R.A.C., janv. 2006. 